\title{
Oral nifedipine versus nitroglycerine patch for tocolysis in preterm labour
}

\author{
Nidhi Sharma ${ }^{1}$, Shikha Rani ${ }^{2 *}$, Anju Huria ${ }^{2}$, Deepak Chawla ${ }^{3}$
}

\author{
${ }^{1}$ Chakravarty Nursing Home, Panchkula, Haryana, India \\ ${ }^{2}$ Department of Obstetrics and Gynecology, ${ }^{3}$ Department of Neonatology, Government Medical College and Hospital, \\ Chandigarh, India
}

Received: 29 October 2018

Accepted: 28 November 2018

\author{
*Correspondence: \\ Dr. Shikha Rani, \\ E-mail: shikhataneja2000@yahoo.co.in
}

Copyright: () the author(s), publisher and licensee Medip Academy. This is an open-access article distributed under the terms of the Creative Commons Attribution Non-Commercial License, which permits unrestricted non-commercial use, distribution, and reproduction in any medium, provided the original work is properly cited.

\begin{abstract}
Background: Preterm delivery is a major cause of neonatal mortality and morbidity. Various modalities have been used to prediction of patient at risk of preterm labor. But due to multi-factorial etiology these predictors are not always useful. Tocolysis has a major role in arresting preterm labor. The purpose of this study was to compare the safety and efficacy of oral nifedipine with transdermal nitroglycerine in the inhibition of preterm labour.

Methods: This single blinded randomized control trial was conducted in the labour room of department of Obstetrics and Gynecology from January 2011 to June 2012. One hundred women with singleton pregnancy between 28 weeks to 34 weeks preterm labour and no contraindication for tocolysis were enrolled in the study. After taking the informed consent subjects were randomized into two groups. Randomization was done by random number table. Fifty-one subjects in nifedipine group received oral nifedipine (Tab Depin 10mg). Forty-nine subjects receiving transdermal nitroglycerine patch (Nitroderm Patch 10) were included in NTG group. The variables analysed were delay in delivery for 48 hours, 7 days or more than 7 days, period of gestation at delivery and side effect profile of drugs.

Results: The percentage of women delivering after 48hours of administration of nifedipine group (52.9\%) and nitroglycerine group $(53.1 \%)$. Failure of tocolysis, defined as delivery within 48 hours, with nitroglycerine group $(32.7 \%)$ was comparable to nifedipine $(33.3 \%)$. Headache was significantly higher in nitroglycerine group as compared to nifedipine group $(\mathrm{p} \leq 0.001)$. Maternal tachycardia was more common in nifedipine group compared to NTG group ( $\mathrm{p}=0.001)$.

Conclusions: Oral nifedipine and transdermal nitroglycerine have similar efficacy as tocolytic agent in patients with preterm labour.
\end{abstract}

Keywords: Nifedipine, Nitroglycerine, Preterm labour, Tocolysis

\section{INTRODUCTION}

Preterm birth remains one of the main causes of perinatal mortality and long-term morbidity. More than $70 \%$ of the total perinatal mortality can be attributed to preterm birth. ${ }^{1}$ Preterm birth is also a major contributor to neonatal morbidities including weakening neurodevelopment capacities, learning impedance, visual disorders and secondary effects in long term health. ${ }^{2}$
Decreasing the preterm birth rate significantly below the current levels may be difficult to achieve because of the association of preterm labour with maternal medical and obstetrical complications and accompanying premature rupture of membranes. ${ }^{3}$ However, Premature birth due to spontaneous preterm labour without any apparent medical or obstetric complications, may be amenable to treatment with tocolytics and may contribute to a significant decrease in the incidence of prematurity and neonatal 
morbidity and mortality. Various methodologies had been used like screening for patients who are at risk of preterm birth, progesterone therapy, treatment of infections and tocolytic therapy. ${ }^{2,3}$

The goal of tocolytic therapy is to reduce neonatal morbidity and mortality by delaying birth, allowing for corticosteroid administration and maternal transfer to a tertiary care centre. ${ }^{4,5}$ Hence, inhibition of preterm labour has assumed special importance in the practice of obstetrics and gynaecology. RCOG states that tocolysis should be considered if a delay of labour for a few days will allow completion of a course of corticosteroids or facilitate in utero transfer. ${ }^{6}$

Different tocolytic agents have been used to inhibit preterm uterine contractions to postpone delivery namely betamimetics, Magnesium sulphate (MgSO4), Prostaglandin synthetase inhibitors, Nitric oxide donors and Calcium channel blockers.

The most commonly studied tocolytic agent is nifedipine, which is calcium channel blocker. It can be administered either orally or sublingually. Nifedipine appears to be a more effective tocolytic agent than $\beta_{2}$-adrenergic-receptor agonists resulting in an improvement in neonatal outcome and is better tolerated than $\beta_{2}$-adrenergic-receptor agonists and magnesium sulfate. ${ }^{7}$

Nitroglycerine (NTG) is a nitric oxide donor, which in turn is a potent endogenous smooth muscle relaxant. Smith et al conducted a randomized, double blind placebo-controlled study with an aim to assess the efficacy of NTG as a tocolytic agent as compared to a placebo. ${ }^{8}$ They found that transdermal nitroglycerine may reduce neonatal morbidity and mortality by decreasing the rate of preterm delivery before 28 weeks, from 20.3 to $10.8 \%$. Amorim et al found similar effectiveness of nitroglycerine and nifedipine in inhibiting preterm labor, with tocolysis achieved within 12 hours among $85 \%$ of women who received nitroglycerine and $87.5 \%$ of those receiving nifedipine. ${ }^{9}$ There are very few studies directly comparing the efficacy and safety of nifedipine and nitroglycerine as a tocolytic agent. ${ }^{9-11}$ Thus, the present study was planned to compare nitroglycerine with nifedipine as tocolytics for preterm labour.

\section{METHODS}

This single blinded randomized control trial was conducted in labour room in department of Obstetrics and Gynaecology from January 2011 to June 2012.

\section{Inclusion criteria}

- One hundred women with singleton pregnancy between 28 weeks to 34 weeks preterm labour without contraindication for tocolysis were enrolled in the study as subjects. ${ }^{3}$

\section{Exclusion criteria}

- Women with hypertensive disorder of pregnancy, antepartum haemorrhage, ruptured membranes or signs/symptoms of chorioamnionitis, cardiac disease, cervical dilatation more than $4 \mathrm{~cm}$, known tocolytic exposure during current pregnancy, intra uterine fetal demise, fetal malformation, severe intra uterine growth restriction and hypotension (BP less than $90 \mathrm{~mm}$ systolic/less than $60 \mathrm{~mm}$ diastolic) were excluded.

Flow diagram 1 shows the process of enrolment of subjects in the study. Informed consent was taken from all enrolled subjects. Randomization was done by random numbers using computer generated random number table.

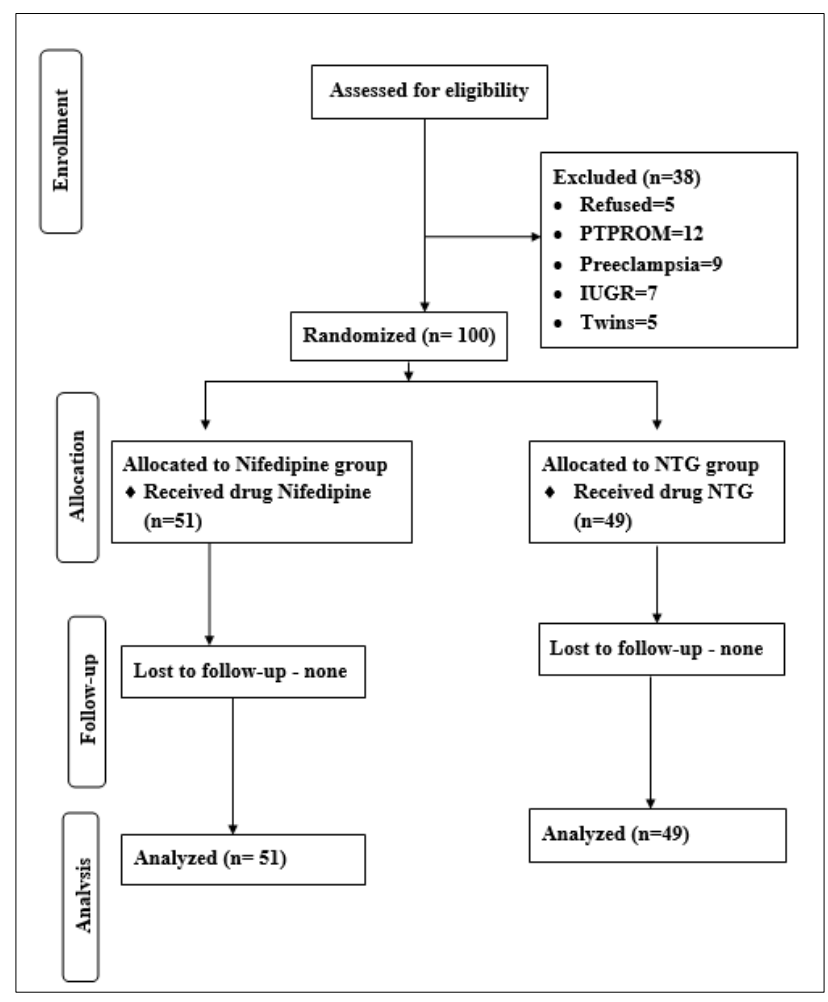

Figure 1: Flow diagram of the progress through the phases of the randomized trial comparing the two drugs.

Nifedipine group had 51 subjects who received oral nifedipine (Tab Depin 10mg). They were given tablet nifedipine $20 \mathrm{mg}$ oral as loading dose. If contractions persisted after sixty minutes, additional oral dose of $10 \mathrm{mg}$ was given. If labour was suppressed after first/second dose, a maintenance dose of $10 \mathrm{mg}$ orally every 6 hours was given starting 6 hours following the loading dose and continued until 48 hours.

NTG group had 49 subjects who received transdermal nitroglycerine patch (Nitroderm 10) which was applied on the abdomen. If contractions persisted at end of 1 hour, an additional patch was applied. Not more than 2 
patches were applied simultaneously $(20 \mathrm{mg})$. At end of 24 hours, it was replaced by another patch for next 24hours. Blood pressure, pulse rate and uterine contractions were recorded hourly for the first 12 hours and then 4 hourly for next 36 hours in both the groups. Both drugs were to be bought by the subjects. Due to the nature of drugs and route of administration only statistician was blinded to the study.

Gestational age was determined by the date of last menstrual period (LMP) with a reliable menstrual history, an early urine pregnancy test and/or an ultrasound prior to 20 weeks of gestation. Demographic profile, detailed history with complete general physical examination including per abdominal examination and sterile per speculum examination to assess cervical dilatation and to exclude any rupture of membranes was done. Subjects were monitored for maternal and fetal wellbeing during the admission. Patients in both groups received injection betamethasone (Betnesol) 12mg intramuscular 2 dosage $24 \mathrm{hrs}$ apart for fetal lung maturity.

If despite adequate therapy of 48 hours, labour progressed or if pulse rate was $\geq 120$ beats $/ \mathrm{min}$ or blood pressure was $\leq 80 / 50 \mathrm{~mm}$ of $\mathrm{Hg}$, drug was discontinued. Inability of the drug to prolong gestation for a minimum period of 48 hours or persistence of uterine contractions even after $20 \mathrm{mg}$ of NTG or $30 \mathrm{mg}$ of nifedipine was considered to be treatment failure. Maternal outcome was measured in terms of duration of prolongation of pregnancy, gestational age at delivery and adverse drug reactions.

\section{Statistical analysis}

Sample size of fifty patients in each group was calculated on the basis of $\alpha$ error of 0.05 and power of 0.80 . Data was entered in MS excel. SPSS-10 was used for statistical analysis. Student's t test and Chi square test were used for the comparison of drugs efficacy for successful tocolysis.

\section{RESULTS}

Authors are reporting a single blinded randomized controlled trial comparing oral nifedipine and transdermal nitroglycerine for tocolysis in preterm labour. The baseline characteristic of subjects in both groups is shown in Table 1. No significant difference with respect to age, period of gestation or previous preterm birth was there between the two groups.

Table 2 shows the comparison of nifedipine and NTG as a tocolytic in preterm labour. Both drugs had equal effect on prolongation of pregnancy by more than $48 \mathrm{hrs}(52.9 \%$ in Nifedipine group, 53.1\% in NTG group, p value=0.99) and till 7 days $(13.7 \%$ in Nifedipine group, $14.3 \%$ in NTG group, $p$ value $=0.94)$. Comparable treatment failure had been found in both the groups (16/51 in Nifedipine group, 17/49 in NTG group, p value=0.94).
Table 1: Baseline characteristics of both groups.

\begin{tabular}{|c|c|c|c|}
\hline Variables & $\begin{array}{l}\text { Nifedipine } \\
\text { group } \\
(\mathbf{n}=\mathbf{5 1})\end{array}$ & $\begin{array}{l}\text { NTG } \\
\text { group } \\
(n=49)\end{array}$ & $\begin{array}{l}\text { p- } \\
\text { value }\end{array}$ \\
\hline Age $(\text { years })^{\mathrm{a}}$ & $24.4 \pm 3.8$ & $24.1 \pm 2.8$ & 0.66 \\
\hline $\begin{array}{l}\text { Period of gestation on } \\
\text { admission (weeks) }\end{array}$ & $32.8 \pm 1.5$ & $33 \pm 1.1$ & 0.39 \\
\hline $\begin{array}{l}\text { Previous preterm } \\
\text { delivery }^{\mathrm{b}}\end{array}$ & $5(18.5 \%)$ & $7(14.2 \%)$ & 0.28 \\
\hline \multicolumn{4}{|l|}{ On admission } \\
\hline $\begin{array}{l}\text { Pulse rate (beats per } \\
\min )^{\mathrm{a}}\end{array}$ & $84.6 \pm 5.2$ & $86.2 \pm 6.8$ & 0.12 \\
\hline $\begin{array}{l}\text { Systolic blood } \\
\text { pressure }(\mathrm{mm} \text { of } \mathrm{Hg})^{\mathrm{a}}\end{array}$ & $114.9 \pm 9.5$ & $111.6 \pm 8.5$ & 0.07 \\
\hline $\begin{array}{l}\text { Diastolic blood } \\
\text { pressure }(\mathrm{mm} \text { of } \mathrm{Hg})^{\mathrm{a}}\end{array}$ & $72.6 \pm 9.1$ & $69.3 \pm 8.6$ & 0.06 \\
\hline Bishop score ${ }^{c}$ & $5(4-6)$ & $5(4-5)$ & 0.98 \\
\hline
\end{tabular}

The most common side effect in NTG group was headache (21/49) which was significantly more than in Nifedipine group $(6 / 51)$ ( $p$ value <.001). These mild headaches were treated with paracetamol. Tachycardia was the most common side effect in Nifedipine group $(23 / 51)$ and was significantly more than NTG group (p value 0.001 ). Six subjects in NTG group and 4 subjects in Nifedipine group had discontinuation of tocolysis due to side effect.

Table 2: Comparison of nifedipine and NTG between the two groups.

\begin{tabular}{|c|c|c|c|}
\hline Variable & $\begin{array}{l}\text { Nifedipine } \\
\text { group } \\
(n=51)\end{array}$ & $\begin{array}{l}\text { NTG } \\
\text { Group } \\
(n=49)\end{array}$ & P value \\
\hline \multicolumn{4}{|c|}{ Prolongation of pregnancy (days) ${ }^{\mathrm{a}}$} \\
\hline$<2$ & $17(33.3 \%)$ & $16(32.7 \%)$ & 0.95 \\
\hline $2-7$ & $27(52.9 \%)$ & $26(53.1 \%)$ & 0.99 \\
\hline$>7$ & $7(13.7 \%)$ & $7(14.3 \%)$ & 0.94 \\
\hline \multicolumn{4}{|c|}{ Completion of antenatal steroid cover ${ }^{\mathrm{a}}$} \\
\hline Yes & $40(78.4 \%)$ & $38(77.6 \%)$ & \multirow{2}{*}{0.91} \\
\hline No & $11(21.6 \%)$ & $11(22.4 \%)$ & \\
\hline $\begin{array}{l}\text { Treatment } \\
\text { failure }^{\mathrm{a}}\end{array}$ & $17(33.3 \%)$ & $16(32.7 \%)$ & 0.95 \\
\hline \multicolumn{4}{|l|}{ Side effects ${ }^{a}$} \\
\hline Headache & $6(11.8 \%)$ & $21(42.9 \%)$ & $<0.001 * *$ \\
\hline Hypotension & $1(2 \%)$ & $7(14.3 \%)$ & $0.03 *$ \\
\hline Tachycardia & $23(45.1 \%)$ & $7(14.3 \%)$ & $0.001 * *$ \\
\hline $\begin{array}{l}\text { Treatment } \\
\text { discontinuation }\end{array}$ & $4(7.8 \%)$ & $6(12.2 \%)$ & 0.52 \\
\hline
\end{tabular}

${ }^{a}$ represent the data in number of patients (\%)

Table 3 compares the fetal outcome in both groups. No statistically significant difference was found in the gestational age at the time of delivery ( $p$ value 0.42 ) and birth weight ( $\mathrm{p}$ value 0.10 ) between the two groups. Birth asphyxia was comparable in two groups $(\mathrm{p}=0.36)$. One 
neonatal death occurred in nifedipine group and there was none in NTG group.

Table 3: Comparison of fetal outcome in both groups.

\begin{tabular}{|c|c|c|c|}
\hline Variable & $\begin{array}{l}\text { Nifedipine } \\
\text { group } \\
(\mathbf{n}=51)\end{array}$ & $\begin{array}{l}\text { NTG } \\
\text { group } \\
(n=49)\end{array}$ & $\begin{array}{l}\text { p- } \\
\text { value }\end{array}$ \\
\hline $\begin{array}{l}\text { Gestational age at } \\
\text { delivery }(\text { weeks) }\end{array}$ & $33.1 \pm 1.5$ & $33.1 \pm 1.1$ & 0.42 \\
\hline Birth weight $(\mathrm{kg})^{\mathrm{a}}$ & $1.79 \pm 0.35$ & $1.81 \pm 0.27$ & 0.10 \\
\hline Apgar score ${ }^{b}$ & $9(9-9)$ & $9(9-9)$ & 0.50 \\
\hline \multicolumn{4}{|c|}{ Neonatal complications ${ }^{c}$} \\
\hline Birth asphyxia & $4(7.8 \%)$ & $1(2 \%)$ & 0.36 \\
\hline Death & $2(3.9 \%)$ & $0(0 \%)$ & 0.49 \\
\hline
\end{tabular}

\section{DISCUSSION}

Primary goal of tocolysis is to have some time to administer antenatal corticosteroid which leads to reduce neonatal morbidity and mortality. In present study, authors found that the prolongation of pregnancy $>2$ days could be achieved in 34/51 and 33/49 in Nifedipine group and NTG group, respectively. Also, the effect of nitroglycerine was non-inferior to nifedipine. Amorim et al enrolled 50 patients and compared the effect of oral nifedipine and NTG as a tocoltyic agent. They found the rate of preterm delivery in the first 48 hours was $15.4 \%$ and $12.5 \%$ respectively in nitroglycerin and nifedipine groups. Both drugs were found to be almost equally efficacious. Headache was significantly more in NTG group than nifedipine (30.8\% versus $8.3 \%, \mathrm{p}=0.04)$. Similar results are found in present study $(42.9 \%$ versus $11.8 \%, \mathrm{p}=0.001) .{ }^{9}$ Dhawle A et al compared the tocolytic effect of nifedipine and NTG in 43 and 41 patients in each group, respectively. They found that delivery within 48 hours, was significantly more with NTG as compared to Nifedipine $(\mathrm{p}=0.02)$. The neonatal outcomes in terms of the mean birth weight, need and duration of neonatal intensive care was similar in both groups as observed in present study too. ${ }^{10}$ Kashanian et al, did a randomised clinical trial comparing NTG and nifedipine as a tocolytic agent. They found that more number of women in NTG group delivered after 48 hours (52 women $(86.7 \%)$ vs 41(68.3\%), $\mathrm{P}=0.016)$ and after 7 days (47 (78.3\%) vs 37 $(61.7 \%), \mathrm{P}=0.046)$, than women in the nifedipine group. Fetal outcomes like Apgar score, neonatal weight were better in NTG group. Also, the neonatal intensive care unit (NICU) admission and duration of NICU stay were less in the NTG group. Adverse effects were similar and minimal in both groups. ${ }^{11}$

The American College of Obstetricians and Gynaecologists supports the use of first-line tocolytic treatment with beta-adrenergic agonist therapy, calcium channel blockers, or NSAIDs for short-term prolongation of pregnancy (up to 48 hours) to allow for the administration of antenatal steroids. However, tocolytic therapy has no direct favourable effect on neonatal outcomes. ${ }^{12}$ As it is a randomized control trial, so this is the strength of present study. However, authors have not compared the cost effectiveness of both drugs is the weakness.

\section{CONCLUSION}

To conclude present study showed transdermal nitroglycerine to be noninferior to oral nifedipine for tocolysis in preterm labor.

\section{Funding: No funding sources}

Conflict of interest: None declared

Ethical approval: The study was approved by the Institutional Ethics Committee

\section{REFERENCES}

1. Slattery MM, Morrison JJ. Preterm delivery. Lancet. 2002;360(9344):1489-97.

2. Blencowe H, Cousens S, Chou D, Oestergaard M, Say L, Moller AB, et al. Born too soon: the global epidemiology of 15 million preterm births. Reprod Heal. 2013;10(1):S2.

3. Cunningham FG, Leveno KJ, Bloom SL, Hauth JC, Spong CY, Dashe JS, Williams Obstetrics $24^{\text {th }}$ ed. NewYork: McGraw Hill Medical Publishing Division; 2014:829-861.

4. Roberts D, Dalziel S. Antenatal corticosteroids for fetal lung maturation accelerating for women at risk of preterm birth. Cochrane Database Syst Rev. 2006;3:CD004454.

5. Crowther CA, Harding JE. Repeat doses of prenatal corticosteroids for women at risk of preterm birth for preventing neonatal respiratory disease. Cochrane Database Syst Rev. 2007;3:CD003935. 11.

6. Royal College of Obstetricians and Gynaecologists. Tocolytic drugs for the women in preterm labour. Clinical Guideline no.1(B), February 2011.

7. Conde-Agudelo A, Romero R, Kusanovic JP. Nifedipine in the management of preterm labor: a systematic review and metaanalysis. Am J Obstet Gynecol. 2011;204:134.e1-20.

8. Smith GN, Walker MC, Ohlsson A, O'Brien K, Windrim R. Randomized double blind placebo controlled trial of transdermal nitroglycerine for preterm labour. Am J Obstet Gynecol. 2007;196:1-8.

9. Amorim MM, Lippo LA, Costa AA, Coutinho IC, Souza AS. Transdermal nitroglycerine administration versus oral nifedipine for tocolysis: A randomized clinical trial. Rev Bras Ginecol Obstet. 2009;31:5528.

10. Dhawle A, Kalra J, Bagga R, Aggarwal N. Nifedipine versus nitroglycerin for acute tocolysis in preterm labour: a randomised controlled trial. Int $\mathbf{J}$ Reprod Contracept Obstet Gynecol. 2013;2:61-6.

11. Kashanian M, Zamen Z, Sheikhansari N. Comparison between nitroglycerin dermal patch and nifedipine for treatment of preterm labor: a 
randomized clinical trial. J Perinatol. 2014;34(9):683-7.

12. American College of Obstetricians and Gynecologists: Management of preterm labor. Practice Bulletin No.171. 2016;128(4).
Cite this article as: Sharma N, Rani S, Huria A, Chawla D. Oral nifedipine versus nitroglycerine patch for tocolysis in preterm labour. Int J Reprod Contracept Obstet Gynecol 2019;8:174-8. 